\section{BMJ Paediatrics Open}

\title{
Communication skills with children in paediatric anaesthesia: challenges while wearing a face mask
}

\author{
Ann-Marie Lydia Crowe
}

To cite: Crowe A-ML. Communication skills with children in paediatric anaesthesia: challenges while wearing a face mask. BMJ Paediatrics Open 2020;4:e000846. doi:10.1136/ bmjpo-2020-000846

Received 18 August 2020 Accepted 16 October 2020
Check for updates

(C) Author(s) (or their employer(s)) 2020. Re-use permitted under CC BY-NC. No commercial re-use. See rights and permissions. Published by BMJ.

Department of Anaesthesia, Children's Health Ireland at Crumlin, Dublin, Ireland

Correspondence to Dr Ann-Marie Lydia Crowe; crowe.annmarie@gmail.com

\section{ABSTRACT}

Effective communication with children is a skill, the importance of which is especially highlighted by the COVID-19 pandemic and the ubiquitous wearing of face masks. Anaesthesiology consultants have been shown to display excellent communication skills that facilitate the development of rapid rapport and patient cooperation. Good communication results in positive interactions for hospitalised children, which correlates with improved healthcare outcomes. However, interactions with a child aren't always straightforward, particularly for trainees unfamiliar with certain communication techniques, which are important to use at a time when when the wearing of face masks is commonplace.

Communication skills with children in the context of anaesthesia provision is a skill, particularly when it comes to induction of anaesthesia. For the uninitiated-namely, anaesthesiology trainees entering into a paediatric anaesthesia rotation-perioperative interactions with a child might not be straightforward, and plans for a smooth anaesthetic induction can be quickly upended. One might shrug and say 'you win some, you lose some' but positive interactions with a child when they visit the hospital are important.

Good communication skills correlate with improved healthcare outcomes. ${ }^{12}$ Conversely, poor communication can have the opposite effect, and result in a difficult induction, distress and postoperative behaviour disturbances. ${ }^{3}$ Anaesthesiologists have been shown to display excellent communication skills that facilitate the development of rapid rapport, cooperation and trust with the patient, especially so in the setting of induction of anaesthesia in children. ${ }^{4}$ It is thus worth considering how such communication skills can be developed.

Induction is the transition from the awake to the anaesthetised state, and can be gaseous (involving the child breathing the anaesthetic agent through a mask) or intravenous (if the placement of a cannula can be negotiated). Unlike the usual doctor-patient dynamic encountered in theatre, this particular interaction typically comprises three members: anaesthesiologist, child and parent. For some, this can lead to a heightened degree of communication difficulty. Discerning nonverbal cues, managing child-parent dynamics, addressing the child's concerns, diffusing parental angst-all while planning, negotiating and delivering an anaesthetic. It takes perception and skill to use suitable, subtle techniques that facilitate a smooth induction.

Misfiring chitchat can lead to a protracted and stressful induction for anaesthesiologist, child and parent. The distress that often accompanies induction can be reduced, however, through good communication. ${ }^{5}$ Anaesthesiologists usually learn their communication skills through modelling of peers, and then develop these skills over decades of clinical interactions with children and their parents. ${ }^{2}$ This too was my experiencepay close attention to what the consultants do, and follow their example. Indeed, most health professionals feel that experience rather than academic coursework has taught them the necessary skills and techniques for communicating with children. ${ }^{6}$ However, the American Board of Pediatrics has recommended that those working in paediatrics engage in specific training programmes in teaching and assessment of communication skills and techniques, ${ }^{7}$ and perhaps it's time we adopt similar programmes.

The ubiquitous wearing of face masks during the COVID-19 pandemic has resulted in communication challenges among those working in paediatrics, with mask-wearing contributing to increased fear and poorer engagement among children in the hospital setting. ${ }^{8}$ In this context, enhancing communication skills among those working with children is key. Experienced anaesthesiologists do not rely exclusively on facial expressions to develop a rapport with a child, and the array of communication techniques they employ to negotiate induction can go unnoticed to 
the untrained eye. Skilled, dynamic use of story-telling, distraction techniques, vivid imagery and other hypotherapeutic techniques are often used, and these can be taught to and employed by the less-experienced anaesthesiology trainees to enhance patient engagement and alleviate fear in theatre.

The array of communication techniques available to successfully negotiate an anaesthetic induction in children do not need to take years to perfect, nor do they need to be taught exclusively in the clinical setting. The emergence of the hidden curriculum as an influential concept in medical education ${ }^{9}$ means that subjects and skills which lie outside the more traditional framework of the formal curriculum are increasingly addressed in clinical education programmes. Setting aside time to deliver a workshop in communication skills with children could be transformative, for anaesthesiologist, parent and child alike, particularly at a time when the wearing of face masks in theatre and outside of it is likely to be in place for the foreseeable future.

Funding The authors have not declared a specific grant for this research from any funding agency in the public, commercial or not-for-profit sectors.

Competing interests None declared.

Patient and public involvement Patients and/or the public were not involved in the design, or conduct, or reporting, or dissemination plans of this research.

Patient consent for publication Not required.

Provenance and peer review Not commissioned; externally peer reviewed.
Open access This is an open access article distributed in accordance with the Creative Commons Attribution Non Commercial (CC BY-NC 4.0) license, which permits others to distribute, remix, adapt, build upon this work non-commercially, and license their derivative works on different terms, provided the original work is properly cited, appropriate credit is given, any changes made indicated, and the use is non-commercial. See: http://creativecommons.org/licenses/by-nc/4.0/.

ORCID iD

Ann-Marie Lydia Crowe http://orcid.org/0000-0001-7536-400X

\section{REFERENCES}

1 Stewart M, Brown JB, Boon $\mathrm{H}$, et al. Evidence on patient-doctor communication. Cancer Prev Control 1999;3:25-30.

2 Cyna AM, Andrew MI, Tan SGM. Communication skills for the anaesthetist. Anaesthesia 2009;64:658-65.

3 Aguilera IM, Patel D, Meakin GH, et al. Perioperative anxiety and postoperative behavioural disturbances in children undergoing intravenous or inhalation induction of anaesthesia. Paediatr Anaesth 2003;13:501-7.

4 Yip P, Middleton P, Cyna AM, et al. Non-pharmacological interventions for assisting the induction of anaesthesia in children. Cochrane Database Syst Rev 2009:CD006447.

5 Carlyle AV, Ching PC, Cyna AM. Communication during induction of paediatric anaesthesia: an observational study. Anaesth Intensive Care 2008;36:180-4.

6 Donnelly M, Kilkelly U. Child-friendly healthcare: delivering on the right to be heard. Med Law Rev 2011;19:27-54.

7 American Board of pediatrics medical ethics Subcommittee: teaching and evaluation of interpersonal skills and ethical decision making in pediatrics. Pediatrics 1987;79:829-34.

8 Shack AR, Arkush L, Reingold S, et al. Masked paediatricians during the COVID-19 pandemic and communication with children. $J$ Paediatr Child Health 2020;56:1475-6.

9 Lempp H, Seale C. The hidden curriculum in undergraduate medical education: qualitative study of medical students' perceptions of teaching. BMJ 2004;329:770-3. 